University of Nebraska - Lincoln

DigitalCommons@University of Nebraska - Lincoln

Faculty Publications in the Biological Sciences

Papers in the Biological Sciences

2003

\title{
Native Thistles: Expendable or Integral to Ecosystem Resistance to Invasion?
}

Svata M. Louda

University of Nebraska - Lincoln, slouda1@unl.edu

Tatyana A. Rand

University of Nebraska - Lincoln, tatyana.rand@ars.usda.gov

Follow this and additional works at: https://digitalcommons.unl.edu/bioscifacpub

Part of the Life Sciences Commons

Louda, Svata M. and Rand, Tatyana A., "Native Thistles: Expendable or Integral to Ecosystem Resistance to Invasion?" (2003). Faculty Publications in the Biological Sciences. 89.

https://digitalcommons.unl.edu/bioscifacpub/89

This Article is brought to you for free and open access by the Papers in the Biological Sciences at DigitalCommons@University of Nebraska - Lincoln. It has been accepted for inclusion in Faculty Publications in the Biological Sciences by an authorized administrator of DigitalCommons@University of Nebraska - Lincoln. 
Published in P. Kareiva and S. Levin, editors, THE IMPORTANCE OF SPECIES, Princeton University Press, 2003. Copyright 2003 Princeton University Press.

\title{
Chapter 1
}

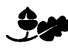

\section{Native Thistles: Expendable or Integral to Ecosystem Resistance to Invasion?}

\author{
Svata M. Louda and Tatyana A. Rand
}

One way of addressing the question of whether some species are expendable is to ask what role, if any, a minor species, even one that seems obnoxious, plays in the functioning of its community. Thistles (Cirsium spp.) are prickly plants native to North America that are numerically minor and are often considered unattractive or undesirable. So, thistles might be considered expendable. Yet, can we assume that such minor, seemingly undesirable species can be eliminated without disrupting important interdependencies or losing key ecological services? Our long-term studies of thistle-insect interactions are beginning to provide evidence that even such species may play important, unexpected roles in ecological dynamics and in economic welfare. These studies suggest that determining the cost of losing a species requires criteria other than relative abundance and general attractiveness (see Root this volume).

In this chapter, we summarize the natural history of the native Cirsium species, which we study in the upper Great Plains. Then, we 
briefly review experimental evidence that the native insects that feed on native thistles can restrict their abundance and weediness. Finally, we present new observational data suggesting that these native insects, moving over from a native species such as tall thistle (Cirsium altissimum (L.) Spreng.), are likely involved in limiting the invasion of bull thistle, Cirsium vulgare (Savi) Ten., in the tallgrass prairie region of Nebraska. Bull thistle is a Eurasian species that is highly invasive elsewhere (Austin et al. 1985; Randall 1991; Julien and Griffiths 1998; Olckers and Hill 1999) and often becomes expensive to control in agronomic regions around the world. Such invasions of nonindigenous species can present major economic and ecological threats to ecosystem structure and functioning (Mooney and Drake 1986; Drake et al. 1989; Simberloff et al. 1997). We hypothesize that our study represents a case of a numerically minor species that, acting as a reservoir of native insects, provides an ecologically and economically valuable ecosystem service: resistance to invasion by an alien weed. The case also suggests that more research on the potential biotic resistance provided by natural enemies may help us better understand those factors that influence whether an alien species becomes invasive after naturalization.

Based on our studies, we argue that there are practical as well as aesthetic and ethical reasons for working to maintain minor, even seemingly obnoxious, species and their interactions. In particular, this case suggests that we are not yet in a position to predict the cost associated with the decline and loss of a specific species, since its ecological function and economic value may not be obvious.

\section{Natural History Background}

The thistle genus Cirsium (L.), indigenous in Eurasia, North America, and North and East Africa, contains about 250 species (Bremer 1994). The North American contingent of this genus is represented by at least 96 indigenous, endemic taxa (USDA, NRCS 1999). We have extensive quantitative data on four native species that are characteristic of the prairie grasslands of the upper Great Plains. All typically occur singly or in small stands, and none are considered major weeds (McCarty et al. 1967; Louda et al. 1990; Stubbendieck et al. 1994). The data presented here are for the native tall thistle (Cirsium altissimum (L.) Spreng.), a late-flowering monocarpic species in the tallgrass region of Nebraska (McCarty et al. 1967), and the naturalized Eurasian thistle species bull (spear) thistle (Cirsium vulgare (Savi) Tenore), also a lateflowering monocarpic species that occurs as small stands in disturbed roadside or overgrazed grassland in Nebraska. Although several alien 
thistles are listed as noxious weeds in Nebraska, bull thistle is not. Our studies of tall and bull thistles were conducted in Lancaster County, east of the City of Lincoln.

As fugitive species, the performance and density of thistles are related to the availability of seed, the level and spacing of disturbance, and the vigor of grass competition (Hamrick 1983; Hamrick and Lee 1987; Louda et al. 1990, 1992; Popay and Medd 1990; Louda and McEachern 1995; Louda and Potvin 1995; Bevill and Louda 1999). Seed availability usually limits local thistle seedling density in open grasslands (see de Jong and Klinkhamer 1986; Louda and McEachern 1995; Louda and Potvin 1995).

Thistles have a suite of adapted insects (Zwölfer 1965, 1988; Lamp and McCarty 1979, 1981, 1982a, b; Redfern 1983; Zwölfer and Romstöck-Völkl 1991). The most common insects specializing on Cirsium species in Nebraska are picture-winged flies (Tephritidae), weevils (Curculionidae), moths (Pyralidae, Pterophoridae), butterflies (Nymphalidae, Hesperiidae), lacebugs (Tingidae), aphids (Aphididae), and sucking bugs (Hemiptera: Cicadellidae, Membracidae, Miridae, Pentatomidae). Several studies demonstrate that these native insects significantly affect key components of individual plant fitness (Louda et al. 1990, 1992; Louda and Potvin 1995; Guretzky and Louda 1997; Stanforth et al. 1997; Bevill 1998; Jackson 1998; Bevill et al. 1999).

There is also evidence that thistle-feeding insects often adopt similar hosts in alternate or novel environments. For example, several thistle-feeding insects have been imported from Eurasia and released in the United States by the U.S. Department of Agriculture as biological control agents for exotic thistles (Julien and Griffiths 1998). At least two of the weevils being distributed for the control of alien thistles have also adopted native species as hosts; these include Rhinocyllus conicus Fröl. (Louda et al. 1997; Louda and Arnett 2000) and Larinus planus (F.) (Louda and O'Brien 2002).

In sum, since insects can reduce plant performance of thistles and since host range expansion in thistle-feeding insects occurs, the potential clearly exists for native insects to adopt potentially invasive thistles as hosts. If this is the case, these insects likely play a role in limiting the reproduction and spread of nonindigenous thistles that are closely related, or ecologically similar, to native species.

\section{Native Insect Herbivores Limit Densities of Indigenous Thistles}

Multiple studies of the role of coevolved insects in the population dynamics of native thistles in prairie grasslands have demonstrated 
clearly that native insects significantly decrease the survival, growth, reproduction, lifetime fitness, and density of native thistles under field conditions. These experiments document significant reductions by insect herbivores of (1) juvenile survivorship and growth (Guretzky and Louda 1997; Stanforth et al. 1997; Bevill et al. 1999), especially in the context of competition with grasses (Louda et al. 1990, 1992); (2) subsequent flowering effort of surviving plants (Bevill 1998; Bevill et al. 1999); (3) successful seed maturation (Louda et al. 1990, 1992; Louda and McEachern 1995; Louda and Potvin 1995; Jackson 1998; Louda 1999a, b; Maron et al. unpub. data); (4) lifetime fitness (Louda and Potvin 1995); and (5) seedling, juvenile, and adult densities (Louda and Potvin 1995). Populations of the monocarpic thistles have been shown to be seed-limited in undamaged prairie grassland (Louda and Potvin 1995). Platte thistle density, for example, increased $100-600 \%$ when floral insect herbivores were reduced, especially in disturbances but also in ungrazed prairie (Louda et al. 1990, 1992; Louda and Potvin 1995). Individually, these studies show that coevolved thistle-feeding insects significantly reduce key parameters of individual plant performance. Collectively, the studies suggest that the chronic pressure exerted by a diverse, dependent assemblage of adapted natural enemies often limits population density and patch regeneration of native thistles in grasslands under indigenous conditions.

\section{Native Thistle Harbors Insects that Attack an Exotic Thistle}

Ecosystem resistance to invasion has been listed as an important property of intact ecosystems (e.g., Daily 1997). One mechanism that produces such resistance to exotic plant invasion is competition from native plants (see Drake et al. 1989; McKnight 1993; Mack 1996). Herbivory by native insects could be another mechanism that reduces the invasiveness of some nonindigenous plant species (Louda 1999b). In this case, insects from a native thistle contribute significant resistance to the potential for invasive population growth and spread by bull (spear) thistle, Cirsium vulgare (Savi) Ten., in eastern Nebraska.

Bull thistle, a Eurasian species, is an aggressive weed in many areas of the world. Its invasive potential is clear from published descriptions, studies, and control efforts in grazed grasslands of Australia, New Zealand, and South Africa (e.g., Austin et al. 1985; Julien and Griffiths 1998; Olckers and Hill 1999) and in natural areas of California (Randall 1991). However, although bull thistle has been present in the tallgrass prairie region of eastern Nebraska for at least 35 years, 
its numbers remain relatively low (C. P. Andersen and S. M. Louda, unpub. data). Contemporary agricultural practices control weeds, including bull thistle, within crop fields, but numbers have also remained low in roadsides and perennial pastures despite disturbance and grazing. Bull thistle is not common enough to be classified as a major weed throughout eastern Nebraska.

Native insects from the indigenous tall thistle have included the potentially invasive Eurasian thistle in their diet. When native insect herbivores fed on developing buds and flowering heads, the seed production of bull thistle in Nebraska was severely reduced. In Lancaster County, for example, insects destroyed $88 \%$ of the potential seed production by bull thistle plants sampled in 1997, $79 \%$ in 1998 , and $71 \%$ in 1999 , significantly reducing the reproductive success of bull thistle (fig. 1.1). At least four insects were often found feeding on or in the reproductive shoots and developing flower heads of bull thistle. These insects were Platyptilia carduidactyla (Riley) (Pterophoridae), Baris subsimilis Casey (Curculionidae), Papaipema mitela Guen. (Noctuidae), and Paracantha culta Wiedeman (Tephritidae). All these species typically feed on or in the reproductive shoots and developing flower heads of the native, tall thistle (Louda, pers. obs.). Feeding by these insects severely reduced the number of flower heads that matured and the number of viable seeds that were produced by the native tall thistle from 1994 to 1995 (Jackson 1998) and from 1997 to 1999 (fig. 1.2), significantly reducing reproductive success. The levels of use of bull thistle were also high, though not as high as those observed on the native tall thistle (see fig. 1.1 vs. fig. 1.2; Jackson 1998; Louda, unpub. data). Thus, the adapted, dependent insects of native thistles are exerting tremendous "pest resistance pressure" on this exotic, potentially invasive weed under its newly adopted conditions in eastern Nebraska.

Our previous experiments, in addition, have shown that herbivory by native insects on tall thistle further limits the survival and growth of young plants (Guretzky and Louda 1997) and the flowering success of older individuals (Jackson 1998). Subsequent competition with grasses for nutrients and moisture, known to restrict the success of established thistles (Austin et al. 1985; Hamrick 1983; Hamrick and Lee 1987; Popay and Medd 1990), likely reduces plant density further by limiting the survival and growth of the seedlings that do establish. If the consequences of insect feeding on bull thistle are similar to those for tall thistle-and this is currently being tested (L. M. Young, unpub. data) - then population growth and the development of high densities of bull thistle are opposed by the pressure exerted on this exotic thistle by native insects, insects-that are adapted to and main- 


\section{Bull thistle (Cirsium vulgare), exotic}

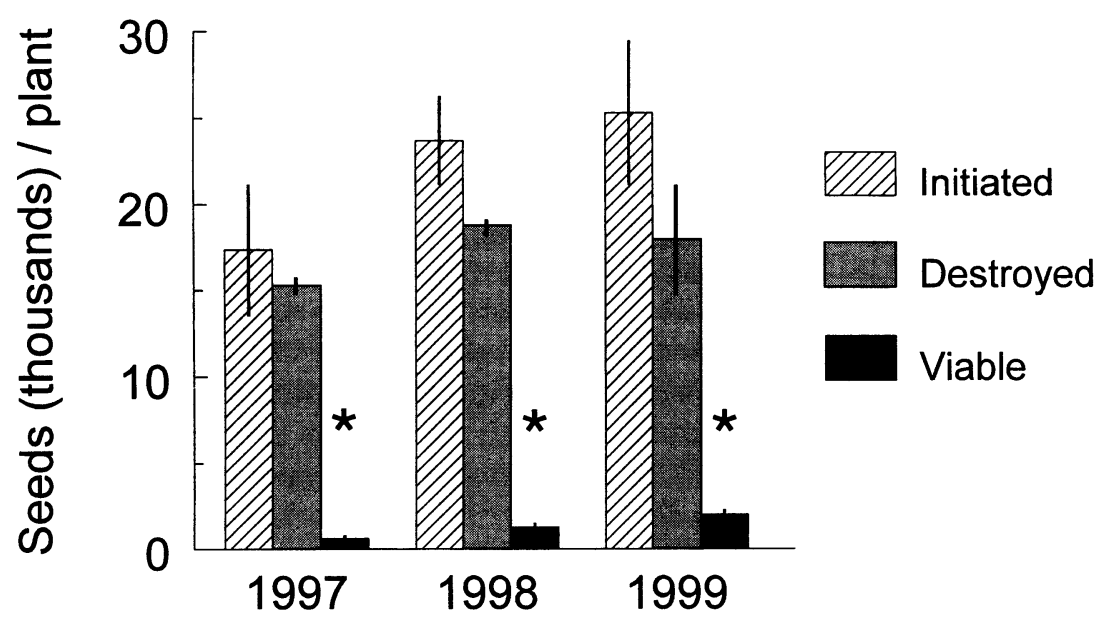

Figure 1.1 Average number $(X, S E)$ of potential seeds as florets initiated; florets and seeds destroyed by feeding of native insects; and viable seeds released per plant by the Eurasian bull (spear) thistle, Cirsium vulgare (Savi) Ten. in Lancaster County, Nebraska ( $N=10,5$, and 10, in 1997, 1998, and 1999, respectively). Native insects, transferring from the co-occurring, late-flowering native thistle (Cirsium altissimum, tall thistle), reduced seed production by this exotic, potentially invasive thistle by $88 \%, 79 \%$, and $71 \%$ in 1997,1998 , and 1999 , respectively. ${ }^{*}=p$ $<0.05$ in orthongonal contrasts.

tained by a thistle native to this region. Disruption of these interactions, through a loss of the native thistle and its reservoir of native insects, would be expected to increase the probability of a full-blown invasion by bull thistle, as has occurred elsewhere. Thus, loss of the native thistle and its insects could create a more noxious, economic weed out of a currently innocuous exotic plant.

\section{Discussion}

The reasons for preserving species are scientific, functional, and practical. First, studies of thistle dynamics and interactions have contributed basic ecological insights into how biological interactions can structure, limit, and influence the numerical abundance and distribution of native plants in grasslands (e.g., Louda et al. 1990, 1992; Louda 


\section{Tall thistle (Cirsium altissimum), native}

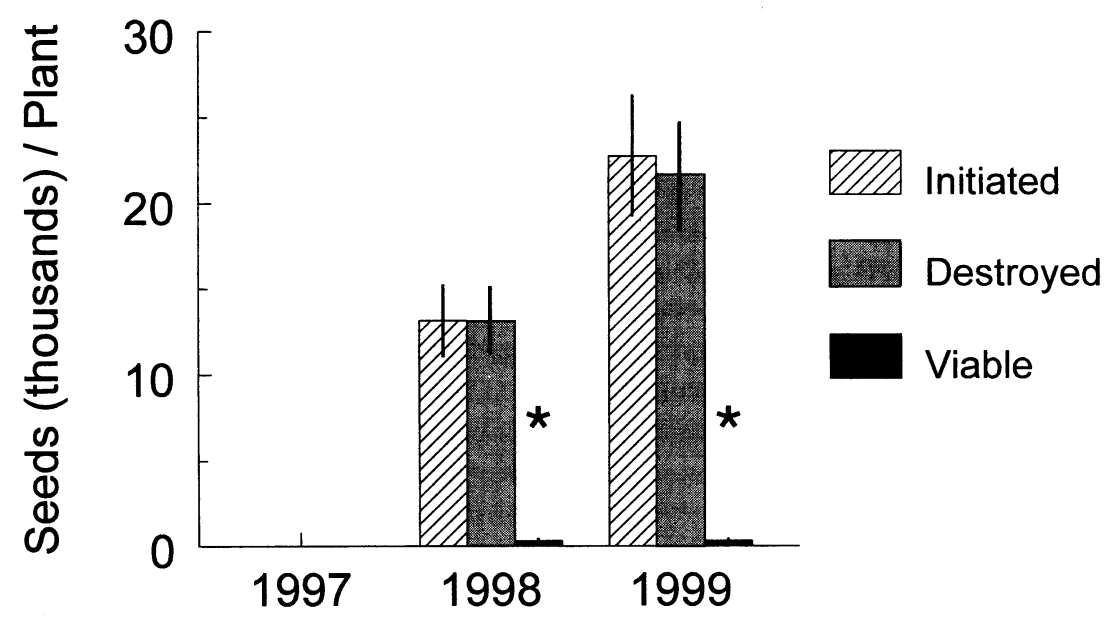

Figure 1.2 Average number ( $\mathrm{X}, \mathrm{SE})$ of potential seeds as florets initiated; florets and seeds destroyed by feeding of native insects; and viable seeds released per plant by the native thistle, Cirsium altissimum (L.) Spreng. (tall thistle) in Lancaster County, Nebraska ( $N=5$ and 10, in 1998 and 1999, respectively). The coevolved, inflorescence-feeding insects reduced seed production by this native thistle species $99.3 \%$ and $94.8 \%$ in 1998 and 1999 , respectively. ${ }^{*}=p<0.05$ in orthongonal contrasts.

and Potvin 1995; Guretzky and Louda 1997; Jackson 1998; Bevill et al. 1999). Furthermore, parallel studies have added to an understanding of the role of interactions in plant rarity (Louda and McEachern 1995; Stanforth et al. 1997; Bevill and Louda 1999; Bevill et al. 1999).

Second, thistles contribute to the support of a broad array of animal species. In the Great Plains prairies, for example, at least 35 other species use native North American thistles (Louda, unpub. data). These species range from microscopic plant parasites (that harbor potentially useful secondary compounds) to macroscopic animals, including charismatic ones (e.g., as the American Goldfinch) and their predators (e.g., raptors) (Louda et al. 1998). Would such species decline if the native thistle were eliminated? No good answer exists yet.

Third, our data suggest that a native thistle can support a set of herbivorous insects that contribute to a major ecosystem service: the limitation of a potential weed. Native insects limit the seed production and density of populations of native thistles in native and disturbed grasslands (Louda and Potvin 1995; Guretzky and Louda 1997; 
Bevill et al. 1999). In addition, these insects are contributing to the suppression of the potentially invasive, exotic bull thistle, Cirsium vulgare.

What important role, then-if any-can minor, seemingly obnoxious species play? In this case, the data suggest that a prickly, inconspicuous native plant, tall thistle, supports insect herbivores that dramatically reduce the seed production of an incipient invasive species, likely constraining the density and the rate of spread of a potentially serious economic and environmental weed. Thus, we hypothesize that elimination of the native tall thistle would likely have at least one negative ecosystem response with economic implications. Its reduction and loss would be expected to cause a reduction of temporally synchronized adapted insects, decreasing resistance to invasion by the exotic species. Bull thistle would likely become a much greater problem - reaching a status similar to that in other rangeland regionswithout indigenous thistles to harbor adapted, thistle-feeding insects.

Following Bob Paine's example, several key experiments are now underway to test the hypothesis of significant ecosystem resistance provided by tall thistle. These experiments will quantify bull thistle response to (1) increased seed input, to address the question of whether population density is proportional to seed availability; (2) the exclusion of native insect herbivores, to address the question of whether potential seed production is limited by resources or factors other than intensive herbivory; and (3) the removal of neighboring native thistles, to address the question of whether proximity of native thistles influences the native insect use of bull thistle directly, as suggested by observational data (C. P. Andersen and S. M. Louda, unpub. data).

We propose that our studies, along with the knowledge that communities are often structured by trophic interactions (Elton 1927; Pimm 1982; Polis and Winemiller 1996), argue that even a naturally sparse, potentially noxious, native species like a thistle cannot necessarily be assumed to be "expendable." Interestingly, the potential functional significance of tall thistle and its dependent insect herbivore guild became evident only in the context of an external challenge: the establishment and potential invasion by bull thistle. Thus, this case illustrates the difficulty of identifying and quantifying an ecosystem service until it is needed. Similarly, Root (this volume) has pointed out that the role a species plays may be altered, or may only become apparent, as a result of changing conditions, such as the colonization of an ecosystem by an exotic species. The novel interactions that may arise as a consequence of such changes make it difficult to predict the role that a species may play in the future.

It is also worth noting that even thistles are not interchangeable in 
their ecosystem functions. In this case, saving an early flowering thistle (e.g., Platte thistle) and its earlier-feeding insects would not be equivalent to saving the late-flowering thistle (tall thistle) whose insects are providing some resistance to invasion by bull thistle. Unlike biotic resistance provided by plant competitors, in which there is likely to be a substantial amount of functional redundancy among plant species, the function provided by specific plants that serve as reservoirs of coevolved natural enemies is likely to be sensitive to the elimination of a specific plant species.

Few studies have quantified the ecosystem resistance to invasion that is provided by indigenous insect herbivores in other systems. In fact, detection could be impossible in many cases, for example if resistance is sufficient to prevent initial colonization and naturalization. Mack (1996) presents floristic data suggesting that naturalization is enhanced for alien species that lack native relatives. He argues that this pattern may be due to the decreased likelihood of host extensions, or shifts, by native natural enemies that have coevolved with native plants onto exotics that are more distantly related to the native flora. Our data are consistent with this suggestion. Clearly, though, the ecosystem service provided by native plants when naturalization is prevented will be exceptionally difficult to detect and document.

Some indirect evidence suggests, however, that feeding by native insects on non-native plant species may be more common and potentially more important than generally thought. For example, host range expansion of native insects onto non-native plant species has been documented for a diverse group of plants, including other exotic thistles such as milk thistle (Silybum marianum Gaertn.) and Italian thistle (Carduus pycnocephalus L.) in southern California (Goeden 1971, 1974), a variety of other nonindigenous herbs (Wheeler 1974; Chew 1977; Berenbaum 1981; Thomas et al. 1987; Evans et al. 1994); and even introduced trees (Fraser and Lawton 1994). Such crossover effects are also common in agricultural systems (e.g., Strong 1974; Strong et al. 1977; Tabashnik 1983) where native host plants serve as "reservoirs" of crop pests (e.g., Herzog and Funderburk 1986). Furthermore, native insects have been manipulated successfully for biological control of exotic weeds (Sheldon and Creed 1995; Newman et al. 1998).

A prominent theory used to explain the invasiveness of exotic plants within novel habitats is that they have been released from their adapted natural enemies, such as insect herbivores, which are assumed to keep them in check within their native habitats (e.g., Andres and Goeden 1971; Crawley 1987; Blossey and Nötzold 1995; Mack 1996). The indirect evidence showing that native insect herbivores often expand their host range onto introduced plants leads to 
the hypothesis that such herbivores could also play a role in limiting exotic plant success in the new environment. This result could keep exotics below invasive levels or even prevent naturalization all together, especially when related native plants support an herbivore guild within the habitat.

Thus, the theory, the indirect evidence, and our data suggest that more investigations are merited. To clarify the role of adapted, indigenous herbivorous insects in providing resistance to plant invasion. More generally, an elucidation of important indirect linkages between plants that are mediated by mobile insects, herbivores, or pollinators will be critical to our ability to predict the community-level implications of the extirpation of individual plant species.

Few individuals are known to admire thistles (although the Scots are a notable exception). Most express a disregard for thistles, native or not, without knowing much about them or their ecological interactions and ecosystem functions. The impact on native North American thistles was not a major factor in the decision to release the biocontrol weevil Rhinocyllus conicus in 1969, in spite of evidence that it would use Cirsium species (Boldt 1997; Gassmann and Louda 2001). Nor is the potential impact of Larinus planus on thistle populations, exotic or native, a factor influencing its redistribution within North America. Distribution continues, in spite of evidence that each of these weevils accepts Cirsium species into its diet and that each can have a major nontarget effect on native species (Louda et al. 1997, 1998; Louda 2000; Louda and Arnett 2000; Louda and O'Brien 2002). Perhaps a disregard for noncharismatic species, especially prickly ones, is understandable. However, neither a lack of charisma nor relative rarity provide an adequate scientific basis for deciding whether a species has a significant ecological function or indirect economic value.

\section{Conclusion}

Our data suggest that thistles-minor species with a mixed or even unfavorable public image-may provide a vital ecosystem service: resistance to invasion by a putative economic and environmental weed. The conflict between our results and the general attitude toward thistles illustrates the need to develop scientific criteria for determining whether a species might be ecologically redundant and therefore potentially dispensable. Even given the motivation to develop such criteria, however, the question remains: could the interdependencies and numerical consequences of eliminating an indigenous thistle be anticipated and predicted in the context of evaluating its expendability? 
The task would be difficult. In our study of tall thistle, intensive studies of thistles and their dependent species were required to document the demographic interconnections and to discover the potential economic value of preserving the species. Furthermore, the ecosystem service provided would not have been detected without the challenge from a potentially invasive species. Thus, it seems clear that we are not in a position to define all species-specific ecological or practical roles. Rather than expendability, the critical issue seems to be this: how can we use and manage natural systems in a way that will minimize the probability that component, potentially important species will be lost?

\section{Acknowledgments}

We thank the many students, colleagues, and family members who have shared in and contributed to these studies of thistles. Bob Paine and his students, Bruce Menge and Paul Dayton, introduced Svata Louda to the challenge of understanding biological interactions in the field; and subsequent academic advisors, including Boyd Collier, Joe Connell, Tom Ebert, Bob Luck, Bill Murdoch, Jim Rodman, and Paul Zedler, continued that process. They all have her appreciation, but they also may bear some responsibility for the outcome! Our studies of thistle-insect interactions could not have been done without the funding provided by the Research Council of the University of $\mathrm{Ne}-$ braska (1984-1997), the National Science Foundation (DEB92-21065, DEB96-15299), and the Nature Conservancy's Rodney Johnson and Katharine Ordway Stewardship Endowments to S.M.L. and the David H. Smith Postdoctoral Fellowship to T.A.R. 